Article

\title{
In Vitro and In Vivo Effect of Peptides Derived from 14-3-3 Paracoccidioides spp. Protein
}

\author{
Liliana Scorzoni 1, Ana Carolina Alves de Paula e Silva ${ }^{1}$, Haroldo Cesar de Oliveira ${ }^{1}$, \\ Claudia Tavares dos Santos 1, Junya de Lacorte Singulani 1, Patricia Akemi Assato 1, Caroline Maria Marcos ${ }^{\text {, }}$ \\ Lariane Teodoro Oliveira ${ }^{1}$, Nathália Ferreira Fregonezi ${ }^{1}$, Diego Conrado Pereira Rossi ${ }^{2}$, \\ Leandro Buffoni Roque da Silva ${ }^{2}$, Carlos Pelleschi Taborda ${ }^{2}$, Ana Marisa Fusco-Almeida ${ }^{1}$ \\ and Maria José Soares Mendes-Giannini ${ }^{1, *}$
}

Citation: Scorzoni, L.; de Paula e Silva, A.C.A.; de Oliveira, H.C.; Santos, C.T; Singulani, J.L.; Assato, P.A.; Marcos, C.M.; Oliveira, L.T.; Fregonezi, N.F.; Rossi, D.C.P.; et al. In Vitro and In Vivo Effect of Peptides Derived from 14-3-3 Paracoccidioides spp. Protein. J. Fungi 2021, 7, 52. https://doi.org/10.3390/ jof7010052

Received: 14 December 2020

Accepted: 5 January 2021

Published: 13 January 2021

Publisher's Note: MDPI stays neutral with regard to jurisdictional claims in published maps and institutional affiliations.

Copyright: (C) 2021 by the authors. Licensee MDPI, Basel, Switzerland. This article is an open access article distributed under the terms and conditions of the Creative Commons Attribution (CC BY) license (http://creativecommons.org/licenses /by/4.0/).
1 School of Pharmaceutical Sciences, São Paulo State University (UNESP), Araraquara, São Paulo 14800-903, Brazil; liliscorzoni@yahoo.com.br (L.S.); ana_alpasi@hotmail.com (A.C.A.d.P.eS.); haroldocdoliveira@gmail.com (H.C.d.O.); claudiats@fcfar.unesp.br (C.T.d.S.); junyadelacorte@yahoo.com.br (J.d.L.S.); patricia.assato@gmail.com (P.A.A.); marcos_caroline@yahoo.com.br (C.M.M.); lariane.t@hotmail.com (L.T.O.); nat-fregonezi@hotmail.com (N.F.F.); ana.marisa@uol.com.br (A.M.F.-A.)

2 Department of Microbiology, Institute of Biomedical Sciences, University of São Paulo, São Paulo 05508-000, Brazil; rossido@ucmail.uc.edu (D.C.P.R.); leandro_br87@hotmail.com (L.B.R.d.S.); taborda@usp.br (C.P.T.)

* Correspondence: maria.giannini@unesp.br

\begin{abstract}
Background: Paracoccidioidomycosis (PCM) is a chronic disease that causes sequelae and requires prolonged treatment; therefore, new therapeutic approaches are necessary. In view of this, three peptides from Paracoccidioides brasiliensis 14-3-3 protein were selected based on its immunogenicity and therapeutic potential. Methods: The in vitro antifungal activity and cytotoxicity of the 14-3-3 peptides were evaluated. The influence of the peptides in immunological and survival aspects was evaluated in vivo, using Galleria mellonella and the expression of antimicrobial peptide genes in Caenorhabditis elegans. Results: None of the peptides were toxic to HaCaT (skin keratinocyte), MRC-5 (lung fibroblast), and A549 (pneumocyte) cell lines, and only P1 exhibited antifungal activity against Paracoccidioides spp. The peptides could induce an immune response in G. mellonella. Moreover, the peptides caused a delay in the death of Paracoccidioides spp. infected larvae. Regarding C. elegans, the three peptides were able to increase the expression of the antimicrobial peptides. These peptides had essential effects on different aspects of Paracoccidioides spp. infection showing potential for a therapeutic vaccine. Future studies using mammalian methods are necessary to validate our findings.
\end{abstract}

Keywords: paracoccidioidomycosis; Paracoccidioides spp.; 14-3-3 protein; Galleria mellonella; Caenorhabditis elegans; vaccine

\section{Introduction}

Globally, 1.2 million people are affected by fungal infections; however, it is difficult to estimate the real incidence of fungal infections since there is no obligatory reporting of these diseases in many countries [1,2]. Paracoccidioidomycosis (PCM) is a fungal disease restricted to Latin American countries, caused by the dimorphic fungi from the Paracoccidioides genus, composed of the species Paracoccidioides brasiliensis, Paracoccidioides lutzii, Paracoccidioides americana, Paracoccidioides restrepiensis and Paracoccidioides venezuelensis [3-5]. PCM is not a compulsory notification infection, which makes difficult the determination of real incidence of this disease. In Brazil it is estimated that the annual incidence ranges from 0.71 to $3.7 / 100,000$ inhabitants [6,7]. 
The infection occurs by inhalation of fungus propagules and affects, in most cases, children/young adults (acute form) or adult men (chronic condition) [6]. This infection has important medical, social, and economic impact since it affects people during the productive life period and also can cause sequelae [8].

The clinical treatment for PCM includes itraconazole, cotrimoxazole (sulfamethoxazole/trimethoprim combination), and for severe cases, amphotericin B [7]. The treatment duration is long ( 9 to 18 months), and the cure is revealed by clinical, microbiological, radiological, and immunological criteria. Moreover, the patient should then undergo clinical and serological evaluation [7].

The adhesion process is the first step towards invasion and is fundamental to fungal infection success [9]. Adhesins are molecules or microbial surface structures that mediate the host-microorganism adhesion and, therefore, the interaction between these two organisms [10]. Even though Paracoccidioides spp. is not a mandatory intracellular pathogen, after adhesion, the fungus can be internalized, and this event is probably associated with the spread of the disease in different tissues [11].

Important adhesins have been described for Paracoccidioides spp. [12-18] and one of them is $\mathrm{Pb}$ 14-3-3, described as being involved in the adhesion to host cell and virulence process of $P$. brasiliensis. Aiming to demonstrate its role in the adhesion process, da Silva et al., [13] used the recombinant 14-3-3 protein. Its antibody showed adhesion inhibition and the localization of 14-3-3 protein in the fungal cell wall using in vitro and in vivo infection models. Assato et al. [17], using partial complementation of Saccharomyces cerevisiae with the $P$. brasiliensis 14-3-3 gene, demonstrated that the $P$. brasiliensis 14-3-3 protein behaved like an adhesin in this non-pathogenic yeast inducing $S$. cerevisiae adherence to epithelial cells. In addition, the S. cerevisiae strain showed increased expression of genes in the ergosterol pathway, the target for azoles [17]. Marcos et al. $[18,19]$, using a 14-3-3- silenced strain of $P$. brasiliensis, demonstrated that in vitro 14-3-3 is important to the interaction with pneumocytes, and in vivo, showed less virulence in both G. mellonella and murine models, causing low granuloma and fungal burden in the last model. In this way, 14-3-3 protein is considered an important virulence factor of Paracoccidioides spp.

Due to ethical issues regarding the use of mammalian models in the research, invertebrate animal models have been well accepted by the scientific community. $G$. mellonella serves as an infection model for different human pathogenic fungi [20-24]. The G. mellonella immune system has a functional and structural similarity with mammalians [25], as the presence of cells denominated hemocytes with phagocytic ability. It produces melanin through the phenoloxidase enzyme, antimicrobial peptides, and superoxide as part of the humoral response [25-28]. Caenorhabditis elegans is a nematode susceptible to infection by pathogenic bacteria and fungi [29-31]. This nematode has been used to study virulence, filamentation, to search for new antifungal compounds, and to study their effectiveness [32-34]. Furthermore, C. elegans counts with an immune system that recognizes and eliminates pathogens and has high genetic homology with vertebrates [35]. The production of antimicrobial peptides such as Ascaris suum antibacterial factor (ASABF), caenacins ( $\mathrm{cnc}$ ), Neuropeptide-Like Protein (npl) class is an essential attribute of the C. elegans immune system in response to microorganisms [29,36-38].

The rising incidence of fungal infections caused by increasingly susceptible patients and different issues regarding actual available antifungal drugs (drug resistance, cost, toxicity, drug-drug interaction) [39-42] makes fungal prevention and treatment search urgent. There are vaccines against different microorganisms responsible for viral and bacterial diseases; however, there is no available vaccine against fungal infections. Based on this, this study aimed to determine candidates of immunogenic peptides from the 143-3 protein and evaluate its biological activity and immunogenic potential in vitro and in vivo. 


\section{Materials and Methods}

2.1. Prediction of Binding Peptides from Paracoccidioides spp. 14-3-3 Protein to Major Histocompatibility Complex (MHC) Class II Mouse Alleles

For the in silico analysis, the NetMHCIIpan-4.0 server was used (https://services.healthtech.dtu.dk/service.php?NetMHCIIpan-4.0). The mouse alleles H2-Iad, H-2-IAb, H-2-IAk, H-2-IAq, H-2-IAs and H-2-IAu were selected. These analyses resulted in three peptides that demonstrated the right binding prediction, here designated as P1, P2, and P3. The peptides were commercially purchased from Peptide 2.0 (Chantilly, VA, USA) for the characterization and biological activity evaluation.

\subsection{Microorganisms and Culture Conditions}

Paracoccidioides brasiliensis (São Paulo, Brazil) strain 18 and P. lutzii Pb01-like (American Type Culture Collection-ATCC MYA-826/Goiania, Brazil) strain 01 from Laboratory of Clinical Mycology, Faculty of Pharmaceutical Sciences, São Paulo State University (UNESP), Araraquara, Brazil were maintained in Fava-Netto agar at $37^{\circ} \mathrm{C}$ for 4-5 days. For the experiments, the Fava-Netto agar culture was transferred to a brain heart infusion (BHI) broth supplemented with $1 \%$ glucose for $3-4$ days at $37^{\circ} \mathrm{C}$ at $150 \mathrm{rpm}$.

\subsection{Cytotoxicity of 14-3-3 Peptides}

Peptides cytotoxicity was performed using the resazurin method, according to Pavan et al. 2010 [43]. For this assay, HaCaT (skin keratinocyte), MRC-5 (lung fibroblast), and A549 (pneumocyte) cell lines, all acquired from the collection of the Banco de Células do Rio de Janeiro-BCRJ, Brazil, were used. For monolayer formation, $10^{6}$ cells $/ \mathrm{mL}$ were plated in a 96-well microplate using Dulbecco's Modified Eagle Medium (DMEM; Gibco; Thermo Fisher Scientific, Carlsbad, CA, USA) supplemented with $10 \%$ fetal bovine serum (FBS) and incubated for $24 \mathrm{~h}$ at $37{ }^{\circ} \mathrm{C}$ with $5 \% \mathrm{CO}_{2}$. Next, the supernatant was removed, the peptides diluted in DMEM at concentrations from 19.5 to $2500 \mu \mathrm{g} / \mathrm{mL}$ were added. As controls were used DMEM medium, cells plus DMEM medium, and cells treated with $30 \%$ dimethyl sulfoxide (DMSO). The plate was incubated for $24 \mathrm{~h}$ at $37{ }^{\circ} \mathrm{C}$ with $5 \% \mathrm{CO}_{2}$. After the incubation, $30 \mu \mathrm{L} /$ well of $0.01 \%$ resazurin were added and incubated for six $\mathrm{h}$ at $37{ }^{\circ} \mathrm{C}$ with $5 \% \mathrm{CO}_{2}$. The readings were taken at $570 / 600 \mathrm{~nm}$, and the results expressed as a percentage of cell viability.

\subsection{Antifungal Activity of 14-3-3 Peptides}

The antifungal activity of the 14-3-3 peptides was evaluated by broth microdilution method, according to de Paula e Silva, et al. [44]. For this, Roswell Park Memorial Institute (RPMI) 1640 medium with L-glutamine and without sodium bicarbonate buffered at $\mathrm{pH}$ 7 with 4-Morpholinepropanesulfonic acid (MOPS) and supplemented with $2 \%$ glucose was used. The Paracoccidioides spp. inoculum concentration was $0.5-2.5 \times 10^{3}$ cells $/ \mathrm{mL}$, and the antifungal activity of the peptides P1, P2 and P3 from 4.9 to $2500 \mu \mathrm{g} / \mathrm{mL}$ were evaluated. Amphotericin B from 0.016 to $8 \mu \mathrm{g} / \mathrm{mL}$ was used as a control. The plates were incubated at $37^{\circ} \mathrm{C}$ with shaking at $150 \mathrm{rpm}$ for $72 \mathrm{~h}$. After that, $20 \mu \mathrm{L} /$ well of Alamar Blue $^{\mathrm{TM}}$ (BioSource International, Invitrogen, Eugene, OR, USA) was added, followed by another $24 \mathrm{~h}$ incubation. The readings were taken at 570/600 nm, and the results expressed as a percentage of fungal cell viability.

\subsection{Paracoccidioides spp. Adhesion Inhibition Assay to the Extracellular Matrix Component or Pneumocytes (A549) Cells}

Then adhesion inhibition assay was performed according to De Oliveira et al. [45]. For this, 96-well Corning ${ }^{\circledR}$ plates were coated with $50 \mu \mathrm{g} / \mathrm{mL}$ laminin (Sigma Aldrich, Saint Louis, MO, USA) for $18 \mathrm{~h}$ at $4{ }^{\circ} \mathrm{C}$. Wells plates were washed three times with phosphate-buffered saline (PBS). Then, the laminin-coated plate was treated with 100 $\mu \mathrm{g} / \mathrm{mL}$ of peptides P1, P2, and P3 for $1 \mathrm{~h}$ at $37^{\circ} \mathrm{C}$. Paracoccidioides spp. at $10^{6}$ cells $/ \mathrm{mL}$ were 
stained with $100 \mu \mathrm{M}$ of 5-(and-6)-carboxyfluorescein diacetate succinimidyl ester (CFDASE) (Sigma Aldrich, Saint Louis, MO, USA) for $20 \mathrm{~min}$ at $37^{\circ} \mathrm{C}$, then $100 \mu \mathrm{L}$ of this inoculum was added to laminin-coated wells and treated with the peptides and incubated for $3 \mathrm{~h}$ at $37^{\circ} \mathrm{C}$. After incubation, the wells were washed carefully three times with PBS to remove fungal cells not adhered to the laminin. One hundred microliters of PBS were added to each well, and with the aid of a tip, the bottom of each well was scraped to remove the yeast adhered to the laminin, this process was repeated twice. The samples were analyzed by flow cytometry using BD FACSCanto equipment (BD Biosciences, San Jose, CA, USA) by acquiring $30 \mathrm{~s}$ in medium mode; afterward, the data were calculated for milliliters. For the evaluation of the effects of peptides in Paracoccidioides spp. adhesion to pneumocytes (A549) cells, $10^{6}$ cells $/ \mathrm{mL}$ were plated in 96-well microplate using Modified Eagle Medium supplemented with $10 \% \mathrm{FBS}$ and incubated for $24 \mathrm{~h}$ at $37^{\circ} \mathrm{C}$ with $5 \% \mathrm{CO}_{2}$. Treatments were realized as described above in the laminin assay. The samples were analyzed by flow cytometry and expressed in fungal-pneumocyte percentage of interaction.

\subsection{G. mellonella Rearing and Experiment Conditions}

G. mellonella larvae were cultivated in the laboratory, according to Jorjão, et al. [46]. Larvae weighting 150-200 mg, active and without dark spots, were selected and incubated at $37^{\circ} \mathrm{C}$, and protected from the light before the experiments. Before treatment/infection, aseptic treatment of the pro-legs was performed with $70 \%$ ethanol. The larvae were inoculated and/or treated using $10 \mu \mathrm{L}$ Hamilton syringes (Hamilton, Reno, NV, USA). In all treatments, larvae were incubated at $37^{\circ} \mathrm{C}$. For each experimental condition, 10-15 larvae were used, and each experiment was repeated at least three times.

\subsubsection{Toxicity Evaluation of 14-3-3 Peptides}

For toxicity, G. mellonella larvae were treated with peptides P1, P2, or P3 at concentrations 10, 20, 40, 100, and $200 \mu \mathrm{g} /$ larva and incubated at $37^{\circ} \mathrm{C}$. Survival was evaluated daily for seven days, as described above.

\subsubsection{Hemocytes Concentration}

G. mellonella were treated with $100 \mu \mathrm{g} / \mathrm{larva}$ of peptides P1, P2, and P3 and incubated for $3 \mathrm{~h}$ at $37^{\circ} \mathrm{C}$. After this period, the larvae hemolymph was removed through an incision with the aid of a scalpel, $10 \mu \mathrm{L}$ of hemolymph was diluted in $90 \mu \mathrm{L}$ of anticoagulant solution (2\% NaCl; $0.1 \mathrm{M}$ glucose; $30 \mathrm{mM}$ sodium citrate; $26 \mathrm{mM}$ citric acid and $10 \mathrm{mM}$ Ethylenediamine tetraacetic acid (EDTA)) and then to $200 \mu \mathrm{L}$ of FACs fluid. Hemocyte counts were performed by flow cytometry in BD FACSCanto equipment (BD Biosciences, San Jose, CA, USA). For that, the number of events was recorded in $60 \mathrm{~s}$ on medium acquisition mode, which is equivalent to $60 \mu \mathrm{L}$ of the sample; afterward, the data were calculated for milliliters. The hemocytes from larvae injected with PBS were compared with the infected ones.

\subsubsection{Induction of Phenoloxidase Activity by Peptides}

The quantification of the phenoloxidase enzyme was performed according to the protocol described by Laughton and Siva-Jothy [47]; for that, the larvae of G. mellonella were treated with $100 \mu \mathrm{g} / \mathrm{larva}$ for $3 \mathrm{~h}$ at $37^{\circ} \mathrm{C}$. Then the hemolymph of 5 larvae was collected and pooled; $50 \mu \mathrm{L}$ of each hemolymph pool was added to $150 \mu \mathrm{L}$ anticoagulant solution and centrifuged for $5 \mathrm{~min}$ at $500 \mathrm{rpm}$ to remove the cells. Aliquots of $50 \mu \mathrm{L}$ of the supernatant were collected, and $50 \mu \mathrm{L}$ of PBS was added to the samples; for positive control, $50 \mu \mathrm{L}$ LPS (lipopolysaccharide) at $2.5 \mathrm{mg} / \mathrm{mL}$, was added instead of PBS, and the plate was incubated for $5 \mathrm{~min}$ at $25^{\circ} \mathrm{C}$. After incubation, $25 \mu \mathrm{L}$ of $6 \mathrm{mM} \mathrm{L}$-dopa was added as a substrate in all samples and incubated for an additional $1 \mathrm{~h}$ at $25^{\circ} \mathrm{C}$. The reading was performed at $490 \mathrm{~nm}$, and the optical density values obtained were analyzed. 


\subsubsection{Analysis of the Expression of Antimicrobial Peptides}

Five G. mellonella larvae per group were treated with $100 \mu \mathrm{g} /$ larva of peptides P1, P2, and P3 and incubated for $3 \mathrm{~h}$ at $37^{\circ} \mathrm{C}$. The hemolymph of all larvae was pooled and diluted in $100 \mu \mathrm{L}$ of anticoagulant solution. RNA extraction was performed using the Trizol reagent (Invitrogen Life Technologies, Carlsbad, CA, USA). The synthesis of the cDNA strand was performed using reverse transcriptase (RevertAid H Minus Reverse Transcriptase, (Fermentas, Waltham, MA, USA). Real-time polymerase chain reaction (PCR) was performed with Maxima ${ }^{\circledR}$ SYBR Green/ROX qPCR Master Mix (2X) (Fermentas, Waltham, MA, USA) using the Applied Biosystems 7500 equipment. The relative expression of the galiomicin and gallerimycin genes was calculated using values $2^{-\Delta \Delta_{\mathrm{CT}}}$ according to Livak and Schmittgen [48], using s7 gene (ribosomal protein) as a housekeeping gene. The primers sequences are described in Table 1.

Table 1. Primers sequence of G. mellonella antimicrobial peptides.

\begin{tabular}{|c|c|c|c|}
\hline Gene & Forward Primer & Reverse Primer & References \\
\hline S7 & ATG TGC CAA TGC CCA AGT TG & GTG GCT AGG CTT GGG AAG AAT & [49] \\
\hline Galiomicin & TCG TAT CGT CAC CGC AAA ATG & GCC GCA ATG ACC ACC TTT ATA & {$[50]$} \\
\hline Gallerimycin & TATCAT TGG CCT TCT TGG CTG & GCA CTCGTA AAA TAC ACA TCC GG & {$[50]$} \\
\hline
\end{tabular}

\subsubsection{Efficacy of 14-3-3 Peptides in G. mellonella Model}

The larvae were treated with $100 \mu \mathrm{g} / \mathrm{larva}$ of peptides P1, P2, and P3 and incubated for $3 \mathrm{~h}$ at $37^{\circ} \mathrm{C}$. After that, the infection with $5 \times 10^{6}$ cells/larvae of $P$. brasiliensis or $P$. lutzii was done, and as a control, larvae were treated with PBS. After the infection, larvae were incubated at $37^{\circ} \mathrm{C}$, and death was monitored daily for seven days, checking the movement after touching them with forceps.

\subsection{Effect of 14-3-3 Peptides on the Induction of C. elegans Antimicrobial Peptides}

C. elegans strain N2 (wild type) synchronized in stage L4 was treated with $250 \mu \mathrm{g} / \mathrm{mL}$ of each of the peptides. After $6 \mathrm{~h}$ of treatment, the worms were washed with $50 \mathrm{mM} \mathrm{NaCl}$ to remove the peptides. RNA extraction, cDNA synthesis, and real-time PCR were performed as described above. The relative expression of the abf-1, abf-3 cnc-4, npl-27, and $n p l-31$ was calculated by $2^{-\Delta \Delta \mathrm{CT}}$ values according to Livak and Schmittgen [48], using actin (act-1) as housekeeping gene. The primers sequences are described in Table 2.

Table 2. Primers sequence of $C$. elegans antimicrobial peptides.

\begin{tabular}{cccc}
\hline Gene & Forward Primer & Reverse Primer & Reference \\
\hline$a b f-1$ & GTACAGCACAGAAATGCATGACCGG & GGCGTTTGAACAACCTCCACAGAAGC & {$[51]$} \\
\hline$a b f-3$ & GGTGTCGAATAAGGCAGTGTGGACCT & GGCATTTCCATAGCTATCCCTGTAGC & {$[51]$} \\
\hline$c n c-4$ & ACAATGGGGCTACGGTCCATAT & ACTTTCCAATGAGCATTCCGAGGA & {$[52]$} \\
\hline$n l p-27$ & CGGTGGAATGCCATATGGTG & ATCGAATTTACTTTCCCCATCC & {$[53]$} \\
\hline$n l p-31$ & GGTGGATATGGAAGAGGTTATGGAG & GTCTATGCTTTTACTTTCCCC & {$[53]$} \\
\hline$a c t-1$ & CCATCATGAAGTGCGACATTG & CATGGTTGATGGGGCAAGAG & {$[53]$} \\
\hline
\end{tabular}

\subsection{Statistical Analysis}

Statistical analysis was performed using GraphPad Prism 6 software (GraphPad Software, Inc., La Jolla, CA, USA). The effects of peptides in hemocytes concentration and phenoloxidase liberation were analyzed by using Kruskal-Wallis and Dunn's tests, and C. elegans antimicrobial peptides real-time PCR. The survival test was analyzed using the Log-rank test (Mantel-Cox). The $p>0.05$ is considered significant in all tests. 


\section{Results}

3.1. In Silico Prediction of Binding Peptides from Paracoccidioides spp. 14-3-3 Protein to Mouse MHC Class II Alleles

The NetMHCIIpan-4.0 algorithm revealed three peptides with a good prediction for binding to mouse MHC class II alleles. The sequences of these peptides are in red (Figure 1), and these were called peptide 1 (P1), peptide 2 (P2), peptide 3 (P3).

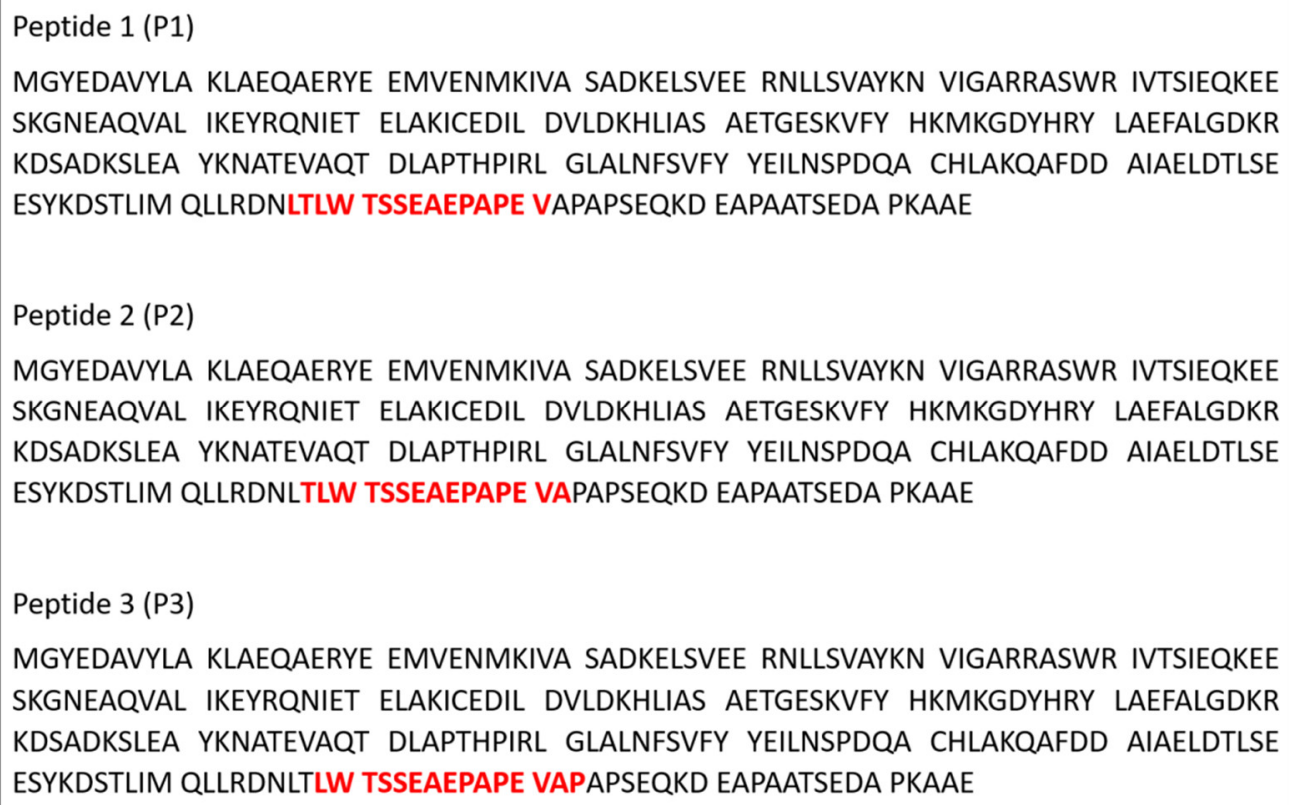

Figure 1. Immunogenic peptides of protein 14-3-3 (GenBank: AY462124.1, PADG_04056 - 14-3-3 family protein epsilon) selected by in silico analysis.

\subsection{Effect of 14-3-3 Peptides in Mammalian Cell}

PCM affects the lungs and skin during the infection; because of this, the peptides from 14-3-3 protein were evaluated regarding its cytotoxicity in lung epithelial cells, lung fibroblasts, and skin keratinocytes at concentrations ranging from 19.5 to $2500 \mu \mathrm{g} / \mathrm{mL}$ (Figure $2 \mathrm{~A}-\mathrm{C}$ ). The peptides treatment showed viability rates above $80 \%$ for all evaluated cell lines, regardless of concentration.

A

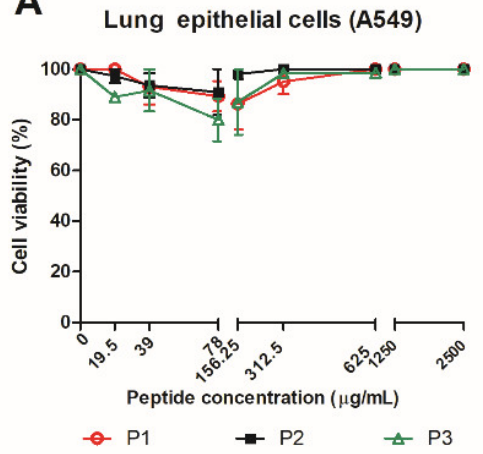

B

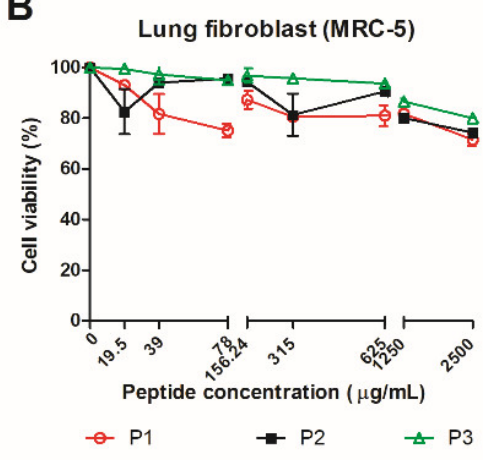

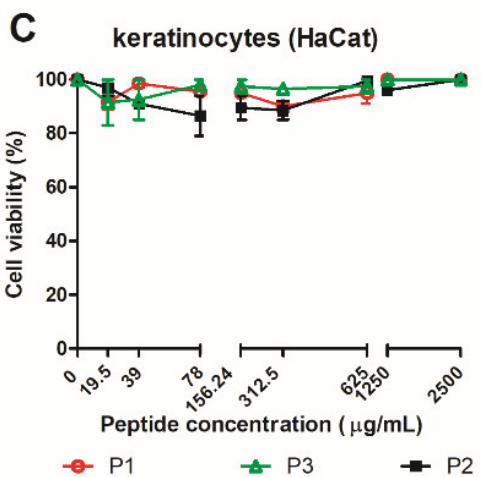

Figure 2. Cytotoxicity of 14-3-3 peptides evaluated in lung epithelial cells (A), lung fibroblasts (B), and skin keratinocytes (C), using the resazurin method. Data expressed as mean \pm standard deviation of two biological replicates and two independent experiments. 


\subsection{Effect of 14-3-3 Peptides on Paracoccidioides spp. Cells}

The broth microdilution assay demonstrated that peptide P1 was the most active peptide and reduced $P$. brasiliensis and $P$. lutzii viability in a concentration-dependent manner. The treatment with $4.9 \mu \mathrm{g} / \mathrm{mL}$ of $\mathrm{P} 1$ reduced the $P$. brasiliensis viability by $30.5 \%$ and $2500 \mu \mathrm{g} / \mathrm{mL}$ was able to reduce $P$. brasiliensis viability by $66 \%$. In a similar way, P1 could reduce the $P$. lutzii viability by $22 \%(39 \mu \mathrm{g} / \mathrm{mL})$ to $70 \%(2500 \mu \mathrm{g} / \mathrm{mL})$ (Figure 3A,B). The peptide P2 did not affect Paracoccidioides spp. viability. On the other hand, P3 at high concentration $(2500 \mu \mathrm{g} / \mathrm{mL})$ reduced P. brasiliensis and P. lutzii viability by $20 \%$ and $30 \%$, respectively.

A

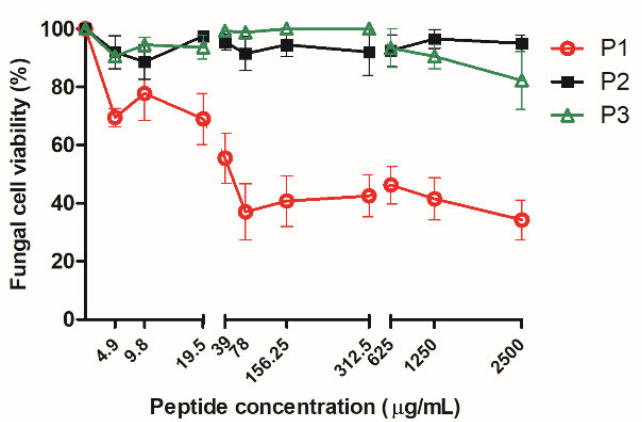

B

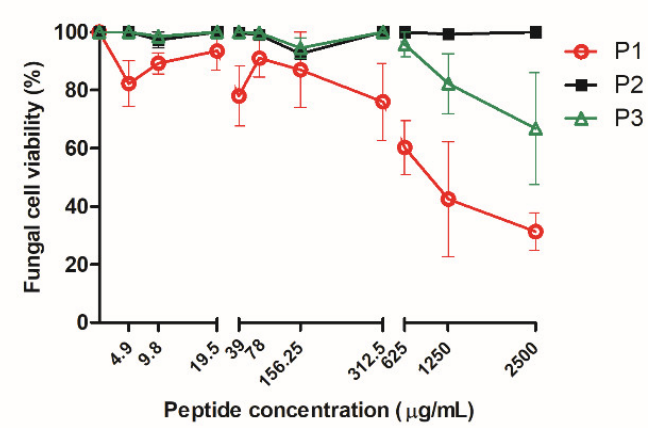

Figure 3. Growth inhibition of 14-3-3 protein peptides (P1, P2, P3) evaluated by microdilution assay against $P$. brasiliensis (A) and P. lutzii (B) concentrations ranging from 4.9 to $2500 \mu \mathrm{g} / \mathrm{mL}$. Data expressed as mean \pm standard deviation of two biological replicates and two independent experiments.

\subsection{Evaluation of the Immunomodulatory and Antifungal Effect in G. mellonella}

Before the evaluation of immunomodulatory and antifungal effect in G. mellonella, the toxicity of the 14-3-3 peptides was assessed at concentrations of 10, 20, 40, $100 \mu \mathrm{g} / \mathrm{larva}$. No larval death was observed in survival curves at the evaluated concentrations, demonstrating that these peptides were not toxic (data not shown). The peptides concentration of $100 \mu \mathrm{g} / \mathrm{larva}$ were selected for the next G. mellonella assays.

\subsubsection{Effect of 14-3-3 Peptides in Hemocytes Concentration}

After $3 \mathrm{~h}$ of treatment with $100 \mu \mathrm{g} /$ larvae of $14-3-3$ protein peptides, a 1.8 -fold increase in G. mellonella hemocytes concentration $(p<0.05)$ was observed for peptides P1 and P2 (Figure 4) when compared to PBS. No statistical difference was observed for the treatment with $\mathrm{P} 3$. 


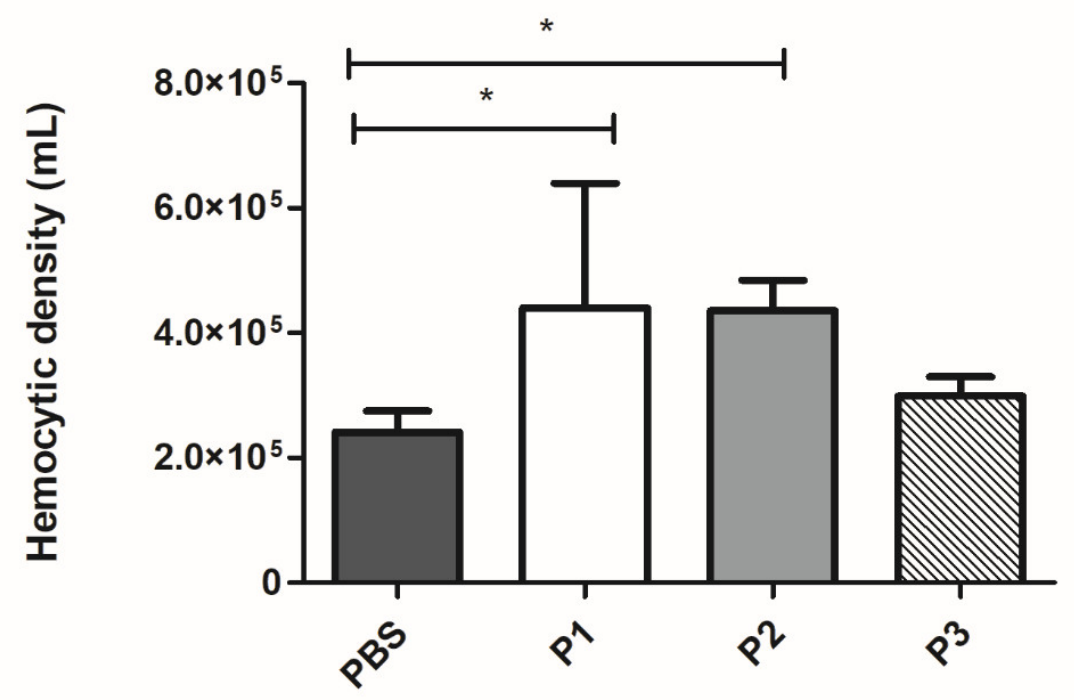

Figure 4. Effect of 14-3-3 peptides in hemocyte concentration of G. mellonella larvae. Data expressed as mean \pm standard deviation of eight to 10 biological replicates and three independent experiments. ${ }^{*} p<0.05$ using Kruskal-Wallis and Dunn's test.

\subsubsection{Effect of 14-3-3 Protein Peptides in Humoral Response of G. mellonella}

As described, phenoloxidase enzyme and antimicrobial peptides are essential factors in the humoral response of G. mellonella against microorganisms. The effect of 14-3-3 peptides in the humoral response of G. mellonella was evaluated in phenoloxidase enzyme and in the expression of genes that encode the antimicrobial peptides galiomicin and gallerimycin. P2 and P3 induce the production of phenoloxidase with a 7.0 and 6.3 -fold increase $(p<0.05)$, respectively when compared to larvae treated with PBS (Figure 5A). Also, P1, P2, and P3 increased galiomicin and gallerimycin genes expression (Figure $5 B, C)$. The most significant increase in peptide expression occurred with the treatment of P1 and P3, respectively, a 15-fold increase for galerimicin and a 6.8-fold increase in galiomycin expression compared to the untreated control.

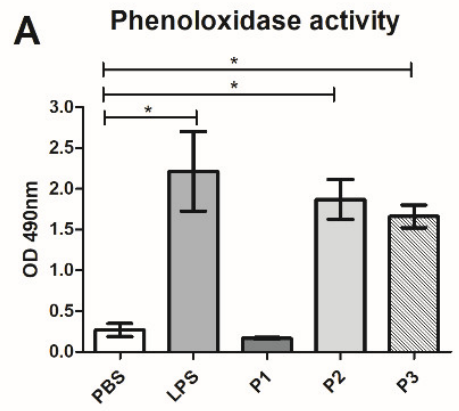

B Galiomicin gene expression

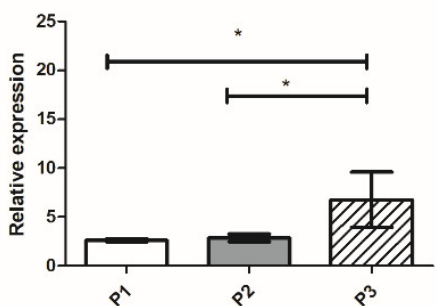

C Gallerimycin gene expression

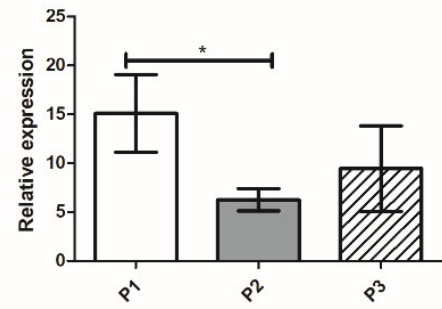

Figure 5. Effect of 14-3-3 protein peptides in humoral response of G. mellonella. Induction of G. mellonella phenoloxidase enzyme after treatment of 14-3-3 peptides using L-dopa as substrate (A). Relative expression G. mellonella of peptides galiomicin (B) and gallerimycin (C) genes after treatment of 14-3-3 peptides. Data expressed as mean \pm standard deviation of three biological replicates and three independent experiments $\left({ }^{*} p<0.05\right)$, using Kruskal-Wallis and Dunn's for phenoloxidase enzyme activity and gene expression using Student's $t$-test. Lipopolysaccharide (LPS).

3.4.3. Antifungal Protective Effect of 14-3-3 Protein Peptides against Paracoccidioides spp. Infection

We also evaluated whether the changes in the immune response of G. mellonella caused by pretreatment with the peptides would affect the survival of larvae infected with 
P. brasiliensis and P. lutzii, which are the most studied etiologic agents of PCM. Although there may have been no statistical difference between the curves, all three peptides led to a delay in the larvae death (Figure 6).
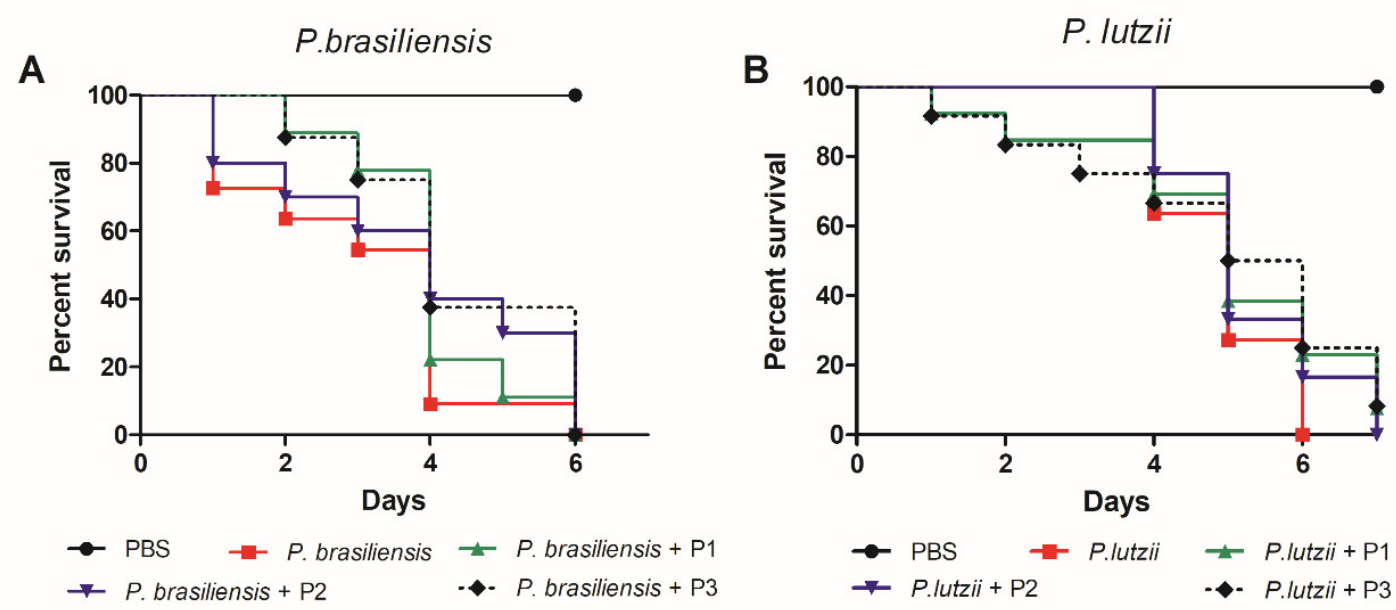

Figure 6. Survival curve of G. mellonella treated with immunogenic peptides at a concentration of $100 \mu \mathrm{g} / \mathrm{larva}$ at $3 \mathrm{~h}$ before the infection with P. brasiliensis (A) or P. lutzii (B). Log-rank test (Mantel-Cox) of eight to 10 biological replicates and three independent experiments $(p<0.05)$.

\subsection{Evaluation of C. elegans Antimicrobial Peptide Expression after Treatment with 14-3-3 Peptides}

The effect of peptides 14-3-3 was evaluated in the C. elegans model, and peptide P3 induced a significant increase of $n p l-31$ (2.9 times), compared to other antimicrobial peptides $(p<0.05)$ (Figure 7).

A

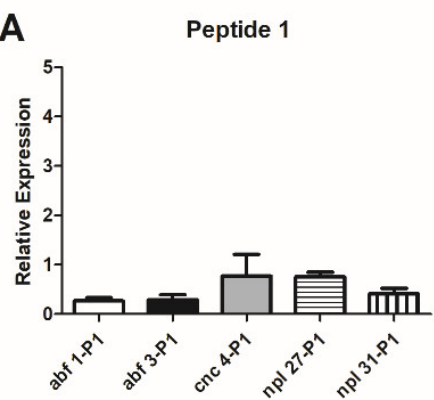

B

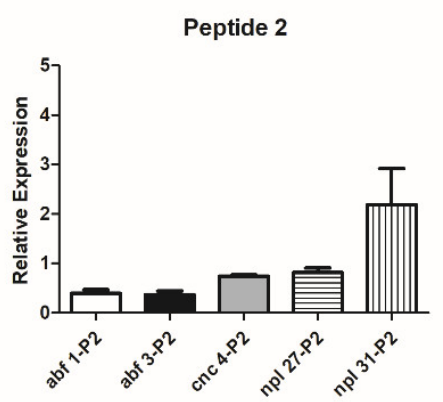

C

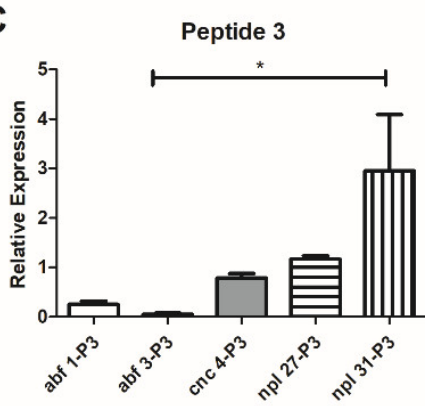

Figure 7. Relative expression of $a b f-1, a b f-3 c n c-4, n p l-27$ and $n p l-31$ genes related to the production of $C$. elegans antimicrobial peptides when in contact with P1 (A), P2 (B) or P3 (C). Data are expressed as mean \pm standard deviation of three biological replicates and three independent experiments $\left({ }^{*} p<0.05\right)$ using Kruskal-Wallis and Dunn's.

Table 3 summarizes the results obtained in vitro and in G. mellonella and C. elegans invertebrate models. 
Table 3. Summary of the 14-3-3 peptides effect in vitro and invertebrate models.

\begin{tabular}{|c|c|c|c|c|c|c|c|c|}
\hline Peptide & $\begin{array}{l}\text { Mammalian } \\
\text { Cell Toxicity }\end{array}$ & $\begin{array}{l}\text { G. mellonella } \\
\text { Toxicity }\end{array}$ & $\begin{array}{l}\text { Antifungal } \\
\text { Activity }\end{array}$ & $\begin{array}{l}\text { Hemocytes } \\
\text { Density }\end{array}$ & $\begin{array}{c}\text { Phenoloxidase } \\
\text { Activity }\end{array}$ & $\begin{array}{c}\text { Expression } G . \\
\text { mellonella } \\
\text { Antimicrobial } \\
\text { Peptides }\end{array}$ & $\begin{array}{c}\text { Protective effect } \\
\text { against } \\
\text { Paracoccidioides } \\
\text { spp. infection in } \\
\text { G. mellonella } \\
\text { model }\end{array}$ & $\begin{array}{c}\text { Expression of } \\
\text { Antimicrobial Peptides } \\
\text { of } C \text {. elegans }\end{array}$ \\
\hline P1 & $\begin{array}{l}\text { Non-toxic } \\
\text { (A549, } \\
\text { HACat and } \\
\text { MRC-5) }\end{array}$ & $\begin{array}{l}\text { Non-toxic } \quad(10- \\
100 \mu g / \text { larva) }\end{array}$ & $\begin{array}{l}\text { P. brasiliensis (30.5- } \\
66 \% \text { of viability } \\
\text { reduction) } \\
\text { P. lutzii (22-70\% of } \\
\text { viability reduction) }\end{array}$ & $\begin{array}{l}\text { 1.8-fold } \\
\text { increase }\end{array}$ & $\begin{array}{l}\text { No statistical } \\
\text { difference }\end{array}$ & $\begin{array}{l}\text { Galiomicin: 2.6- } \\
\text { fold-increase } \\
\text { Gallerimycin:15- } \\
\text { fold-increase }\end{array}$ & $\begin{array}{c}\text { Delay in the larvae } \\
\text { death }\end{array}$ & $\begin{array}{c}a b f-1: 0.26 \text {-fold-increase } \\
a b f-3: 0.29 \text {-fold- increase } \\
\text { cnc-4: 0.77-fold- increase } \\
n p l-27: 0.75 \text {-fold- } \\
\text { increase } \\
n p l-31: 0.40 \text {-fold } \\
\text { increase }\end{array}$ \\
\hline P2 & $\begin{array}{l}\text { Non-toxic } \\
\text { (A549, } \\
\text { HACat and } \\
\text { MRC-5) }\end{array}$ & $\begin{array}{c}\text { Non-toxic (10- } \\
100 \mu \mathrm{g} / \text { larva) }\end{array}$ & $\begin{array}{c}\text { No antifungal } \\
\text { activity against } \\
\text { Paracoccidioides spp. }\end{array}$ & $\begin{array}{l}1.8 \text {-fold } \\
\text { increase }\end{array}$ & 7-fold increase & $\begin{array}{l}\text { Galiomicin: } 2.8 \\
\text { fold-increase } \\
\text { Gallerimycin: } 6.2 \\
\text { fold-increase }\end{array}$ & $\begin{array}{c}\text { Delay in the larvae } \\
\text { death }\end{array}$ & $\begin{array}{c}a b f-1: 0.39 \text {-fold-increase } \\
a b f-3: 0.36 \text {-fold- increase } \\
\text { cnc-4: 0.73-fold- increase } \\
n p l-27: 0.81 \text {-fold- } \\
\text { increase } \\
n p l-31: 2.17 \text {-fold } \\
\text { increase }\end{array}$ \\
\hline P3 & $\begin{array}{l}\text { Non-toxic } \\
\text { (A549, } \\
\text { HACat and } \\
\text { MRC-5) }\end{array}$ & $\begin{array}{c}\text { Non-toxic (10- } \\
100 \mu \mathrm{g} / \text { larva) }\end{array}$ & $\begin{array}{c}\text { P. brasiliensis }(20 \% \\
\text { of viability } \\
\text { reduction) } \\
\text { P. lutzii ( } 30 \% \text { of } \\
\text { viability reduction } \\
\text { at } 2500 \mu \mathrm{g} / \mathrm{mL})\end{array}$ & $\begin{array}{c}\text { No } \\
\text { statistical } \\
\text { difference }\end{array}$ & $\begin{array}{l}\text { 6.3-fold } \\
\text { increase }\end{array}$ & $\begin{array}{l}\text { Galiomicin: } 6.7 \\
\text { folds-increase } \\
\text { Gallerimycin: 6.8- } \\
\text { fold increase }\end{array}$ & $\begin{array}{c}\text { Delay in the larvae } \\
\text { death }\end{array}$ & $\begin{array}{c}a b f-1: 0.20 \text {-fold-increase } \\
a b f-3: 0.05 \text {-fold- increase } \\
\text { cnc-4: } 0.78 \text {-fold- increase } \\
n p l-27: 1.16 \text {-fold- } \\
\text { increase } \\
n p l-31: 2.9 \text {-fold increase }\end{array}$ \\
\hline
\end{tabular}




\section{Discussion and Conclusions}

Mycoses are a threat to immunosuppressed and immunocompetent patients [2,54]. PCM is the most prominent systemic mycosis in Latin America due to its high incidence, long period of treatment, and the sequelae that can affect patients in the most productive life period [6-8]. Considering these factors, the search for alternatives to prevention and treatment is urgent. Different approaches have been investigated in the search for a safe and effective immunization or vaccination therapy for invasive mycoses such as the use of monoclonal antibodies [55], peptide vaccine [56,57], vaccines based on nanotechnology [58], and DNA vaccine [59].

The 14-3-3 protein is an important virulence factor of Paracoccidioides spp. acting as an essential adhesin [17-19]. Therefore, we aimed to determine candidates of immunogenic peptides from this protein and evaluate their biological activity and immunogenic potential in vitro and in vivo. Three peptides of 14-3-3 protein were obtained based on MHC class II alleles binding properties using in silico methods. The cytotoxicity was analyzed using skin keratinocytes, lung fibroblasts, and pneumocytes. The peptides were not toxic for these cells, leading to a small reduction $(20 \%)$ viability. Therefore, a reduction in viability below $30 \%$ is acceptable in cytotoxicity testing, according to ISO 10993-5 (2009).

The antifungal activity against Paracoccidioides spp. showed that the peptide P1 was the most effective in reducing Paracoccidioides spp. viability around $30.5-70 \%$ at concentrations between 4.9 and $2500 \mu \mathrm{g} / \mathrm{mL}$. On the other hand, the pneumocytes treatment with 14-3-3 peptides followed by Paracoccidioides spp. infection was not effective at inhibiting the host-cell interaction of $P$. brasiliensis or $P$. lutzii. Similar results were observed when the extracellular matrix component (laminin) was treated with 14-3-3 peptides and further infected (Figure A1). This peptide originates from an adhesin of the fungus itself, and possibly is not associated with the adhesion role. Thus, inhibition of adhesion to the components of the extracellular matrix or interaction with cells is not a property of this peptide.

Next, 14-3-3 peptides characterization was expanded for in vivo assay using the G. mellonella invertebrate model. The 14-3-3 peptides were not toxic for the larvae and could increase the larvae hemocyte density compared to the control. The increase in the hemocyte density is an essential aspect of the cellular immune response in G. mellonella associated with eliminating infections [60]. Previous data showed that infection by Paracoccidioides spp. reduces the density of hemocytes [22]; therefore, the induction of these cells is an essential strategy for treating larvae infected with this fungus. The challenge of G. mellonella with a sublethal dose of Aspergillus fumigatus increased the hemocyte concentration and the resistance of larvae to this infection [61]. Hemocyte concentration increases with the peptides' treatment derived from a phage library with anti-adhesive activity for Paracoccidioides spp. [62]. The treatment of G. mellonella infected with Candida haemulonii with copper (II), manganese (II), and silver (I) 1,10phenanthroline chelates significantly increased the hemocyte concentration, larvae survival, and reduced fungal burden [63]. Treatment and pretreatment of larvae infected with Candida auris with crude extract and derivatives of the culture supernatant fraction of Lactobacillus paracasei 28.4, a postbiotic, increased hemocytes level of infected larvae [64].

In our study, we demonstrated that P2 and P3 were able to induce phenoloxidase production. Melanization is a vital process in the immune response of invertebrates. It occurs by activating the pro-phenoloxidase cascade generating toxic intermediates such as quinones, and the final product is melanin. Various components of the membrane and cell wall of microorganisms such as PAMPS (pathogen associated molecular patterns), peptidoglycans, lipopolysaccharide, and $\beta-1-3$ glucan (cell wall lipopolysaccharides) participate in the activation of the pro-phenoloxidase. Also, enzymes released by the invertebrate itself due to tissue damage by microorganisms can stimulate the cascade [65]. These substances are very toxic to microorganisms and help in phagocytosis and 
invertebrate survival [66]. As already described, G. mellonella larvae infected with a sublethal dose of C. albicans could induce phenoloxidase activity [67].

Another essential attribute of the G. mellonella immune system is the production of antimicrobial peptides. In this study, 14-3-3 peptides increased the expression of gallerimycin and galiomicin peptides. A significant increase of galiomicin occurred after treatment with P1. The P3 peptide was able to increase the expression of both antimicrobial peptides. The relation between these antimicrobial peptides with infection control has already been demonstrated in different microorganisms. The pretreatment of G. mellonella larvae with Photorhabdus luminescens killed by heat with subsequent infection by this bacterium increased gallerimycin and galiomycin expression and, consequently, the survival of the larvae [68]. Another study demonstrated that sublethal doses of $C$. albicans and A. fumigatus induced the expression of the same antimicrobial peptides $[50,61]$. Furthermore, the infection of G. mellonella with Bacillus subtilis and Bacillus atrophaeus vegetative and sporulating forms also increased gallerimycin and galliomycin expression [69]. The pre-infection with B. subtilis and B. atrophaeus increased gallerimycin and galiomicin expression and survival of larvae infected with $C$. albicans. On the other hand, the treatment with peptides delayed larvae death when they were infected with $P$. brasiliensis or P. lutzii.

The effect of 14-3-3 peptides was also evaluated on the expression of $C$. elegans antimicrobial peptides. The treatment promoted an increase of peptides from Ascaris suum antibacterial factor (ASABF), caenacins ( $\mathrm{cnc})$, neuropeptide-Like protein $(\mathrm{npl})$ class. Different signaling cascades are involved in the C. elegans response against pathogens, such as pathways involving protein kinases (MAPKs), homologous to TGF- $\beta$, insulin-like peptides, and Toll-like receptors. These cascades are responsible for the expression of antimicrobial peptides [52]. An increasing number of reports have demonstrated the importance of these peptides' expression in protecting C. elegans against different fungal and bacterial pathogens $[51,53,70,71]$; thus, $14-3-3$ peptides proved to be beneficial in $C$. elegans.

Due to the fungus' complexity, attenuated, or inactivated, whole cells for immunization can generate unwanted responses. Predictions of epitope biology for selecting peptides capable of inducing the immune response are alternatives in searching for vaccines [57]. A significant advance in the research of a possible PCM vaccine was made using one peptide of the gp43 P. brasiliensis protein (P10), which is an adhesin and significant diagnostic antigen of this mycosis. By using different vaccine approaches, the P10 peptide was able to reduce the fungal burden and to increase cytokine production [59,72-75].

This study characterized three peptides derived from the protein 14-3-3 of $P$. brasiliensis. The peptides induced an immune response in G. mellonella and C. elegans, invertebrate animal models demonstrating their potential. Although a positive correlation has been reported between invertebrates and mammals' models [30], further studies are needed to evaluate these peptides in this model.

Author Contributions: Conceptualization, L.S., C.P.T., A.M.F.-A. and M.J.S.M.-G.; methodology, L.S., A.C.A.d.P.eS., H.C.d.O., C.T.d.S., J.d.L.S., P.A.A., C.M.M., L.T.O., N.F.F., D.C.P.R. and L.B.R.d.S.; formal analysis, L.S., A.C.A.d.P.eS., H.C.d.O., C.T.d.S., J.d.L.S., P.A.A. and C.M.M.; writing - original draft preparation, L.S., C.P.T., A.M.F.-A. and M.J.S.M.-G.; writing - review and editing, L.S., M.J.S.M.-G., A.M.F.-A. and C.P.T.; supervision, M.J.S.M.-G.; project administration, M.J.S.M.-G.; funding acquisition, M.J.S.M.-G. All authors have read and agreed to the published version of the manuscript.

Funding: This research was funded by the Brazilian organizations Fundação de Amparo à Pesquisa do Estado de São Paulo (FAPESP), FAPESP grant numbers (LS) 2013/10917-9, (HdO) 2015/14023-8, (CMM) 2016/17048-4, (JLS) 2014/10446-9, (MM-G) 2015/03700-9 and 2016/08730-6. Rede Nacional de Métodos Alternativos-Conselho Nacional de Desenvolvimento Científico e Tecnológico (RENAMA-CNPq) 403586/2012-7, Conselho Nacional de Desenvolvimento Científico e Tecnológico (CNPq), Coordenação de Aperfeiçoamento Pessoal de Nível Superior (CAPES) and Programa de 
Apoio ao Desenvolvimento Científico da Faculdade de Ciências Farmacêuticas da UNESP PADCFCF-UNESP.

Data Availability Statement: The data presented in this study are available in the article.

Acknowledgments: The authors would like to thank the multi-user Flow Cytometry Laboratory at the Núcleo de Proteômica of the Faculty of Pharmaceutical Sciences at UNESP in Araraquara.

Conflicts of Interest: The authors declare no conflict of interest.

Appendix A

\section{A}

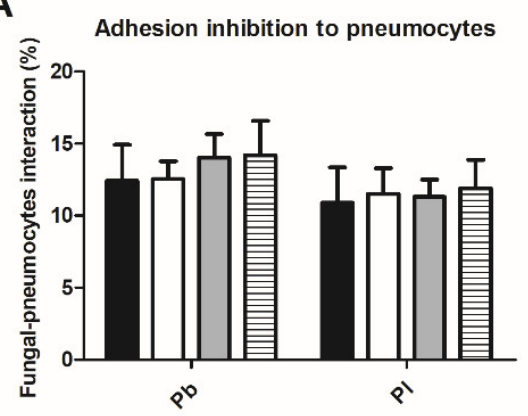

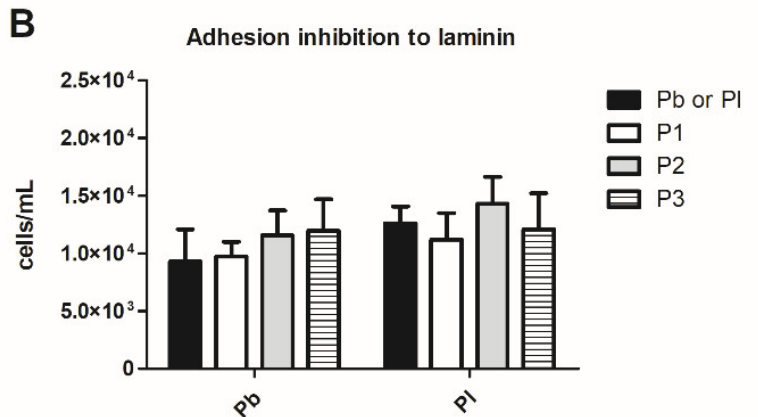

Figure A1. Effect of 14-3-3 peptides treatment in the adhesion to pneumocytes (A) or laminin (B). Data are expressed as mean \pm standard deviation of eight biological replicates and three independent experiments using Kruskal-Wallis and Dunn's $(p<0.05)$.

\section{References}

1. Brown, G.D.; Denning, D.W.; Gow, N.A.; Levitz, S.M.; Netea, M.G.; White, T.C. Hidden killers: Human fungal infections. Sci. Transl. Med. 2012, 4, 165rv13, doi:10.1126/scitranslmed.3004404.

2. Jampilek, J. How can we bolster the antifungal drug discovery pipeline? Future Med. Chem. 2016, 8, 1393-1397, doi:10.4155/fmc2016-0124.

3. Teixeira, M.M.; Theodoro, R.C.; de Carvalho, M.J.; Fernandes, L.; Paes, H.C.; Hahn, R.C.; Mendoza, L.; Bagagli, E.; San-Blas, G.; Felipe, M.S. Phylogenetic analysis reveals a high level of speciation in the Paracoccidioides genus. Mol. Phylogenet. Evol. 2009, 52, 273-283, doi:10.1016/j.ympev.2009.04.005.

4. Munoz, J.F.; Farrer, R.A.; Desjardins, C.A.; Gallo, J.E.; Sykes, S.; Sakthikumar, S.; Misas, E.; Whiston, E.A.; Bagagli, E.; Soares, C.M.; et al. Genome Diversity, Recombination, and Virulence across the Major Lineages of Paracoccidioides. $m$ Sphere 2016, 1, e00213-16, doi:10.1128/mSphere.00213-16.

5. Turissini, D.A.; Gomez, O.M.; Teixeira, M.M.; McEwen, J.G.; Matute, D.R. Species boundaries in the human pathogen Paracoccidioides. Fungal Genet. Biol. 2017, 106, 9-25, doi:10.1016/j.fgb.2017.05.007.

6. Martinez, R. New Trends in Paracoccidioidomycosis Epidemiology. J. Fungi 2017, 3, 1, doi:10.3390/jof3010001.

7. Shikanai-Yasuda, M.A.; Mendes, R.P.; Colombo, A.L.; Queiroz-Telles, F.; Kono, A.S.G.; Paniago, A.M.M.; Nathan, A.; Valle, A.C.F.D.; Bagagli, E.; Benard, G.; et al. Brazilian guidelines for the clinical management of paracoccidioidomycosis. Rev. Soc. Bras. Med. Trop. 2017, 50, 715-740, doi:10.1590/0037-8682-0230-2017.

8. Martinez, R. Epidemiology of paracoccidioidomycosis. Rev. Inst. Med. Trop. Sao Paulo 2015, 57 (Suppl. 19), 11-20, doi:10.1590/S0036-46652015000700004.

9. Filler, S.G.; Sheppard, D.C. Fungal invasion of normally non-phagocytic host cells. PLoS Pathog. 2006, 2, e129, doi:10.1371/journal.ppat.0020129.

10. Pigosso, L.L.; Parente, A.F.; Coelho, A.S.; Silva, L.P.; Borges, C.L.; Bailão, A.M.; Soares, C.M. Comparative proteomics in the genus Paracoccidioides. Fungal Genet. Biol. 2013, 60, 87-100, doi:10.1016/j.fgb.2013.07.008.

11. Mendes-Giannini, M.J.; Hanna, S.A.; da Silva, J.L.; Andreotti, P.F.; Vincenzi, L.R.; Benard, G.; Lenzi, H.L.; Soares, C.P. Invasion of epithelial mammalian cells by Paracoccidioides brasiliensis leads to cytoskeletal rearrangement and apoptosis of the host cell. Microbes Infect. 2004, 6, 882-891, doi:10.1016/j.micinf.2004.05.005.

12. Marcos, C.M.; de Fátima da Silva, J.; de Oliveira, H.C.; Moraes da Silva, R.A.; Mendes-Giannini, M.J.; Fusco-Almeida, A.M. Surface-expressed enolase contributes to the adhesion of Paracoccidioides brasiliensis to host cells. FEMS Yeast Res. 2012, 12, 557570, doi:10.1111/j.1567-1364.2012.00806.x.

13. da Silva, J.d.F.; de Oliveira, H.C.; Marcos, C.M.; da Silva, R.A.; da Costa, T.A.; Calich, V.L.; Almeida, A.M.; Mendes-Giannini, M.J. Paracoccidoides brasiliensis 30 kDa Adhesin: Identification as a 14-3-3 Protein, Cloning and Subcellular Localization in Infection Models. PLoS ONE 2013, 8, e62533, doi:10.1371/journal.pone.0062533. 
14. Nogueira, S.V.; Fonseca, F.L.; Rodrigues, M.L.; Mundodi, V.; Abi-Chacra, E.A.; Winters, M.S.; Alderete, J.F.; de Almeida Soares, C.M. Paracoccidioides brasiliensis enolase is a surface protein that binds plasminogen and mediates interaction of yeast forms with host cells. Infect. Immun. 2010, 78, 4040-4050, doi:10.1128/IAI.00221-10.

15. Torres, I.; Hernandez, O.; Tamayo, D.; Muñoz, J.F.; Leitão, N.P.; García, A.M.; Restrepo, A.; Puccia, R.; McEwen, J.G. Inhibition of PbGP43 expression may suggest that gp43 is a virulence factor in Paracoccidioides brasiliensis. PLoS ONE 2013, 8, e68434, doi:10.1371/journal.pone.0068434.

16. da Silva Neto, B.R.; de Fátima da Silva, J.; Mendes-Giannini, M.J.; Lenzi, H.L.; de Almeida Soares, C.M.; Pereira, M. The malate synthase of Paracoccidioides brasiliensis is a linked surface protein that behaves as an anchorless adhesin. BMC Microbiol. 2009, 9, 272, doi:10.1186/1471-2180-9-272.

17. Assato, P.A.; da Silva, J.d.F.; de Oliveira, H.C.; Marcos, C.M.; Rossi, D.; Valentini, S.R.; Mendes-Giannini, M.J.; Zanelli, C.F.; Fusco-Almeida, A.M. Functional analysis of Paracoccidioides brasiliensis 14-3-3 adhesin expressed in Saccharomyces cerevisiae. BMC Microbiol. 2015, 15, 256, doi:10.1186/s12866-015-0586-2.

18. Marcos, C.M.; da Silva, J.d.F.; de Oliveira, H.C.; Assato, P.A.; Singulani, J.L.; Lopez, A.M.; Tamayo, D.P.; Hernandez-Ruiz, O.; McEwen, J.G.; Mendes-Giannini, M.J.; et al. Decreased expression of 14-3-3 in Paracoccidioides brasiliensis confirms its involvement in fungal pathogenesis. Virulence 2016, 16, 72-84, doi:10.1080/21505594.2015.1122166.

19. Marcos, C.M.; de Oliveira, H.C.; Assato, P.A.; de Andrade, C.R.; Fusco-Almeida, A.M.; Mendes-Giannini, M.J.S. Paracoccidioides brasiliensis 14-3-3 protein is important for virulence in a murine model. Med. Mycol. 2019, 57, 900-904, doi:10.1093/mmy/myy112.

20. Rossi, S.A.; Trevijano-Contador, N.; Scorzoni, L.; Mesa-Arango, A.C.; de Oliveira, H.C.; Werther, K.; de Freitas Raso, T.; MendesGiannini, M.J.; Zaragoza, O.; Fusco-Almeida, A.M. Impact of Resistance to Fluconazole on Virulence and Morphological Aspects of Cryptococcus neoformans and Cryptococcus gattii Isolates. Front. Microbiol. 2016, 7, 153, doi:10.3389/fmicb.2016.00153.

21. Gago, S.; García-Rodas, R.; Cuesta, I.; Mellado, E.; Alastruey-Izquierdo, A. Candida parapsilosis, Candida orthopsilosis, and Candida metapsilosis virulence in the non-conventional host Galleria mellonella. Virulence 2014, 5, 278-285, doi:10.4161/viru.26973.

22. Scorzoni, L.; Alves de Paula e Silva, A.C.; Singulani, J.d.L.; Leite, F.S.; de Oliveira, H.C.; Moraes da Silva, R.A.; Fusco-Almeida, A.M.; Soares Mendes-Giannini, M.J. Comparison of virulence between Paracoccidioides brasiliensis and Paracoccidioides lutzii using Galleria mellonella as a host model. Virulence 2015, 6, 766-776, doi:10.1080/21505594.2015.1085277.

23. Maurer, E.; Browne, N.; Surlis, C.; Jukic, E.; Moser, P.; Kavanagh, K.; Lass-Flörl, C.; Binder, U. Galleria mellonella as a host model to study Aspergillus terreus virulence and amphotericin B resistance. Virulence 2015, 6, 591-598, doi:10.1080/21505594.2015.1045183.

24. Maurer, E.; Hortnagl, C.; Lackner, M.; Grassle, D.; Naschberger, V.; Moser, P.; Segal, E.; Semis, M.; Lass-Florl, C.; Binder, U. Galleria mellonella as a model system to study virulence potential of mucormycetes and evaluation of antifungal treatment. Med. Mycol. 2019, 57, 351-362, doi:10.1093/mmy/myy042.

25. Pereira, T.C.; de Barros, P.P.; Fugisaki, L.R.O.; Rossoni, R.D.; Ribeiro, F.C.; de Menezes, R.T.; Junqueira, J.C.; Scorzoni, L. Recent Advances in the Use of Galleria mellonella Model to Study Immune Responses against Human Pathogens. J. Fungi 2018, 4, 128, doi:10.3390/jof4040128.

26. Sheehan, G.; Kavanagh, K. Analysis of the early cellular and humoral responses of Galleria mellonella larvae to infection by Candida albicans. Virulence 2018, 9, 163-172, doi:10.1080/21505594.2017.1370174.

27. Browne, N.; Heelan, M.; Kavanagh, K. An analysis of the structural and functional similarities of insect hemocytes and mammalian phagocytes. Virulence 2013, 4, 597-603, doi:10.4161/viru.25906.

28. Wojda, I. Immunity of the greater wax moth Galleria mellonella. Insect Sci. 2017, 24, 342-357, doi:10.1111/1744-7917.12325.

29. Souza, A.C.R.; Fuchs, B.B.; Alves, V.S.; Jayamani, E.; Colombo, A.L.; Mylonakis, E. Pathogenesis of the Candida parapsilosis Complex in the Model Host Caenorhabditis elegans. Genes 2018, 9, 401, doi:10.3390/genes9080401.

30. Desalermos, A.; Tan, X.; Rajamuthiah, R.; Arvanitis, M.; Wang, Y.; Li, D.; Kourkoumpetis, T.K.; Fuchs, B.B.; Mylonakis, E. A multi-host approach for the systematic analysis of virulence factors in Cryptococcus neoformans. J. Infect. Dis. 2015, 211, 298-305, doi:10.1093/infdis/jiu441.

31. Zaborin, A.; Romanowski, K.; Gerdes, S.; Holbrook, C.; Lepine, F.; Long, J.; Poroyko, V.; Diggle, S.P.; Wilke, A.; Righetti, K.; et al. Red death in Caenorhabditis elegans caused by Pseudomonas aeruginosa PAO1. Proc. Natl. Acad. Sci. USA 2009, 106, 6327-6332, doi:10.1073/pnas.0813199106.

32. Espinal, P.; Pantel, A.; Rolo, D.; Marti, S.; Lopez-Rojas, R.; Smani, Y.; Pachon, J.; Vila, J.; Lavigne, J.P. Relationship Between Different Resistance Mechanisms and Virulence in Acinetobacter baumannii. Microb. Drug Resist. 2019, 25, 752-760, doi:10.1089/mdr.2018.0182.

33. Manoharan, R.K.; Lee, J.H.; Kim, Y.G.; Kim, S.I.; Lee, J. Inhibitory effects of the essential oils alpha-longipinene and linalool on biofilm formation and hyphal growth of Candida albicans. Biofouling 2017, 33, 143-155, doi:10.1080/08927014.2017.1280731.

34. de Barros, P.P.; Scorzoni, L.; Ribeiro, F.C.; Fugisaki, L.R.O.; Fuchs, B.B.; Mylonakis, E.; Jorge, A.O.C.; Junqueira, J.C.; Rossoni, R.D. Lactobacillus paracasei 28.4 reduces in vitro hyphae formation of Candida albicans and prevents the filamentation in an experimental model of Caenorhabditis elegans. Microb. Pathog. 2018, 117, 80-87, doi:10.1016/j.micpath.2018.02.019.

35. Madende, M.; Albertyn, J.; Sebolai, O.; Pohl, C.H. Caenorhabditis elegans as a model animal for investigating fungal pathogenesis. Med. Microbiol. Immunol. 2020, 209, 1-13, doi:10.1007/s00430-019-00635-4. 
36. Scorzoni, L.; de Lucas, M.P.; Singulani, J.L.; de Oliveira, H.C.; Assato, P.A.; Fusco-Almeida, A.M.; Mendes-Giannini, M.J.S. Evaluation of Caenorhabditis elegans as a host model for Paracoccidioides brasiliensis and Paracoccidioides lutzii. Pathog. Dis. 2018, 76, doi:10.1093/femspd/fty004.

37. Mallo, G.V.; Kurz, C.L.; Couillault, C.; Pujol, N.; Granjeaud, S.; Kohara, Y.; Ewbank, J.J. Inducible antibacterial defense system in C. elegans. Curr. Biol. 2002, 12, 1209-1214, doi:10.1016/s0960-9822(02)00928-4.

38. Muhammed, M.; Fuchs, B.B.; Wu, M.P.; Breger, J.; Coleman, J.J.; Mylonakis, E. The role of mycelium production and a MAPKmediated immune response in the C. elegans-Fusarium model system. Med. Mycol. 2012, 50, 488-496, doi:10.3109/13693786.2011.648217.

39. Ong, C.W.; Chen, S.C.; Clark, J.E.; Halliday, C.L.; Kidd, S.E.; Marriott, D.J.; Marshall, C.L.; Morris, A.J.; Morrissey, C.O.; Roy, R.; et al. Diagnosis, management and prevention of Candida auris in hospitals: Position statement of the Australasian Society for Infectious Diseases. Intern. Med. J. 2019, 10.1111/imj.14612, doi:10.1111/imj.14612.

40. Benedict, K.; Jackson, B.R.; Chiller, T.; Beer, K.D. Estimation of Direct Healthcare Costs of Fungal Diseases in the United States. Clin. Infect. Dis. 2019, 68, 1791-1797, doi:10.1093/cid/ciy776.

41. Hendrickson, J.A.; Hu, C.; Aitken, S.L.; Beyda, N. Antifungal Resistance: A Concerning Trend for the Present and Future. Curr. Infect. Dis. Rep. 2019, 21, 47, doi:10.1007/s11908-019-0702-9.

42. Perfect, J.R. The antifungal pipeline: A reality check. Nat. Rev. Drug Discov. 2017, 16, 603-616, doi:10.1038/nrd.2017.46.

43. Pavan, F.R.; da S Maia, P.I.; Leite, S.R.; Deflon, V.M.; Batista, A.A.; Sato, D.N.; Franzblau, S.G.; Leite, C.Q. Thiosemicarbazones, semicarbazones, dithiocarbazates and hydrazide/hydrazones: Anti-Mycobacterium tuberculosis activity and cytotoxicity. Eur. J. Med. Chem. 2010, 45, 1898-1905, doi:10.1016/j.ejmech.2010.01.028.

44. de Paula e Silva, A.C.; Oliveira, H.C.; Silva, J.F.; Sangalli-Leite, F.; Scorzoni, L.; Fusco-Almeida, A.M.; Mendes-Giannini, M.J. Microplate alamarBlue assay for Paracoccidioides susceptibility testing. J. Clin. Microbiol. 2013, 51, 1250-1252, doi:10.1128/JCM.02914-12.

45. de Oliveira, H.C.; da Silva, J.d.F.; Scorzoni, L.; Marcos, C.M.; Rossi, S.A.; de Paula E Silva, A.C.; Assato, P.A.; da Silva, R.A.; Fusco-Almeida, A.M.; Mendes-Giannini, M.J. Importance of adhesins in virulence of Paracoccidioides spp. Front. Microbiol. 2015, 6, 303, doi:10.3389/fmicb.2015.00303.

46. Jorjão, A.L.; Oliveira, L.D.; Scorzoni, L.; Figueiredo-Godoi, L.M.A.; Prata, M.C.A.; Jorge, A.O.C.; Junqueira, J.C. From moths to caterpillars: Ideal conditions for Galleria mellonella rearing for in vivo microbiological studies. Virulence 2018, 9, 383-389, doi:10.1080/21505594.2017.1397871.

47. Laughton, A.M.; Siva-Jothy, M.T. A standardised protocol for measuring phenoloxidase and prophenoloxidase in the honey bee, Apis mellifera. Apidologie 2011, 42, 140-149, doi:10.1051/apido/2010046.

48. Livak, K.J.; Schmittgen, T.D. Analysis of relative gene expression data using real-time quantitative PCR and the 2(- $\Delta \Delta \mathrm{C}(\mathrm{T}))$ Method. Methods 2001, 25, 402-408, doi:10.1006/meth.2001.1262.

49. Wojda, I.; Jakubowicz, T. Humoral immune response upon mild heat-shock conditions in Galleria mellonella larvae. J. Insect Physiol. 2007, 53, 1134-1144, doi:10.1016/j.jinsphys.2007.06.003.

50. Bergin, D.; Murphy, L.; Keenan, J.; Clynes, M.; Kavanagh, K. Pre-exposure to yeast protects larvae of Galleria mellonella from a subsequent lethal infection by Candida albicans and is mediated by the increased expression of antimicrobial peptides. Microbes Infect. 2006, 8, 2105-2112, doi:10.1016/j.micinf.2006.03.005.

51. Alper, S.; McBride, S.J.; Lackford, B.; Freedman, J.H.; Schwartz, D.A. Specificity and complexity of the Caenorhabditis elegans innate immune response. Mol. Cell. Biol. 2007, 27, 5544-5553, doi:10.1128/MCB.02070-06.

52. Zugasti, O.; Ewbank, J.J. Neuroimmune regulation of antimicrobial peptide expression by a noncanonical TGF-beta signaling pathway in Caenorhabditis elegans epidermis. Nat. Immunol. 2009, 10, 249-256, doi:10.1038/ni.1700.

53. Pujol, N.; Zugasti, O.; Wong, D.; Couillault, C.; Kurz, C.L.; Schulenburg, H.; Ewbank, J.J. Anti-fungal innate immunity in C. elegans is enhanced by evolutionary diversification of antimicrobial peptides. PLoS Pathog. 2008, 4, e1000105, doi:10.1371/journal.ppat.1000105.

54. Brown, G.D.; Denning, D.W.; Levitz, S.M. Tackling Human Fungal Infections. Science 2012, 336, 647-647, doi:10.1126/science.1222236.

55. Boniche, C.; Rossi, S.A.; Kischkel, B.; Barbalho, F.V.; Moura, A.N.D.; Nosanchuk, J.D.; Travassos, L.R.; Taborda, C.P. Immunotherapy against Systemic Fungal Infections Based on Monoclonal Antibodies. J. Fungi 2020, 6, 31, doi:10.3390/jof6010031.

56. Travassos, L.R.; Taborda, C.P. Linear Epitopes of Paracoccidioides brasiliensis and Other Fungal Agents of Human Systemic Mycoses As Vaccine Candidates. Front. Immunol. 2017, 8, 224, doi:10.3389/fimmu.2017.00224.

57. Da Silva, L.B.R.; Taborda, C.P.; Nosanchuk, J.D. Advances in Fungal Peptide Vaccines. J. Fungi 2020, 6, 119, doi:10.3390/jof6030119.

58. Kischkel, B.; Rossi, S.A.; Santos, S.R.; Nosanchuk, J.D.; Travassos, L.R.; Taborda, C.P. Therapies and Vaccines Based on Nanoparticles for the Treatment of Systemic Fungal Infections. Front. Cell. Infect. Microbiol. 2020, 10, 463, doi:10.3389/fcimb.2020.00463.

59. Rittner, G.M.; Muñoz, J.E.; Marques, A.F.; Nosanchuk, J.D.; Taborda, C.P.; Travassos, L.R. Therapeutic DNA vaccine encoding peptide P10 against experimental paracoccidioidomycosis. PLoS Negl. Trop. Dis. 2012, 6, e1519, doi:10.1371/journal.pntd.0001519. 
60. Bergin, D.; Brennan, M.; Kavanagh, K. Fluctuations in haemocyte density and microbial load may be used as indicators of fungal pathogenicity in larvae of Galleria mellonella. Microbes Infect. 2003, 5, 1389-1395, doi:S1286457903002612.

61. Fallon, J.P.; Troy, N.; Kavanagh, K. Pre-exposure of Galleria mellonella larvae to different doses of Aspergillus fumigatus conidia causes differential activation of cellular and humoral immune responses. Virulence 2011, 2, 413-421, doi:10.4161/viru.2.5.17811.

62. de Oliveira, H.C.; Michaloski, J.S.; da Silva, J.d.F.; Scorzoni, L.; de Paula E Silva, A.C.; Marcos, C.M.; Assato, P.A.; Yamazaki, D.S.; Fusco-Almeida, A.M.; Giordano, R.J.; et al. Peptides Derived from a Phage Display Library Inhibit Adhesion and Protect the Host against Infection by Paracoccidioides brasiliensis and Paracoccidioides lutzii. Front. Pharm. 2016, 7, 509, doi:10.3389/fphar.2016.00509.

63. Gandra, R.M.; McCarron, P.; Viganor, L.; Fernandes, M.F.; Kavanagh, K.; McCann, M.; Branquinha, M.H.; Santos, A.L.S.; Howe, O.; Devereux, M. In vivo Activity of Copper(II), Manganese(II), and Silver(I) 1,10-Phenanthroline Chelates Against Candida haemulonii Using the Galleria mellonella Model. Front. Microbiol. 2020, 11, 470, doi:10.3389/fmicb.2020.00470.

64. Rossoni, R.D.; de Barros, P.P.; Mendonca, I.D.C.; Medina, R.P.; Silva, D.H.S.; Fuchs, B.B.; Junqueira, J.C.; Mylonakis, E. The Postbiotic Activity of Lactobacillus paracasei 28.4 Against Candida auris. Front Cell Infect. Microbiol. 2020, 10, 397, doi:10.3389/fcimb.2020.00397.

65. Cerenius, L.; Lee, B.L.; Soderhall, K. The proPO-system: Pros and cons for its role in invertebrate immunity. Trends Immunol. 2008, 29, 263-271, doi:10.1016/j.it.2008.02.009.

66. Binggeli, O.; Neyen, C.; Poidevin, M.; Lemaitre, B. Prophenoloxidase activation is required for survival to microbial infections in Drosophila. PLoS Pathog. 2014, 10, e1004067, doi:10.1371/journal.ppat.1004067.

67. Vertyporokh, L.; Wojda, I. Immune response of Galleria mellonella after injection with non-lethal and lethal dosages of Candida albicans. J. Invertebr. Pathol. 2020, 170, 107327, doi:10.1016/j.jip.2020.107327.

68. Wu, G.; Zhao, Z.; Liu, C.; Qiu, L. Priming Galleria mellonella (Lepidoptera: Pyralidae) larvae with heat-killed bacterial cells induced an enhanced immune protection against Photorhabdus luminescens TT01 and the role of innate immunity in the process. J. Econ. Entomol. 2014, 107, 559-569, doi:10.1603/ec13455.

69. Barros, P.P.; Rossoni, R.D.; Ribeiro, F.C.; Silva, M.P.; Souza, C.M.; Jorge, A.O.C.; Junqueira, J.C. Two sporulated Bacillus enhance immunity in Galleria mellonella protecting against Candida albicans. Microb. Pathog. 2019, 132, 335-342, doi:10.1016/j.micpath.2019.05.023.

70. Ermolaeva, M.A.; Schumacher, B. Insights from the worm: The C. elegans model for innate immunity. Semin. Immunol. 2014, 26, 303-309, doi:10.1016/j.smim.2014.04.005.

71. Pukkila-Worley, R.; Ausubel, F.M.; Mylonakis, E. Candida albicans infection of Caenorhabditis elegans induces antifungal immune defenses. PLoS Pathog. 2011, 7, e1002074, doi:10.1371/journal.ppat.1002074.

72. Magalhães, A.; Ferreira, K.S.; Almeida, S.R.; Nosanchuk, J.D.; Travassos, L.R.; Taborda, C.P. Prophylactic and therapeutic vaccination using dendritic cells primed with peptide 10 derived from the 43-kilodalton glycoprotein of Paracoccidioides brasiliensis. Clin. Vaccine Immunol. 2012, 19, 23-29, doi:10.1128/CVI.05414-11.

73. Muñoz, J.E.; Luft, V.D.; Amorim, J.; Magalhães, A.; Thomaz, L.; Nosanchuk, J.D.; Travassos, L.R.; Taborda, C.P. Immunization with P10 peptide increases specific immunity and protects immunosuppressed BALB/c mice infected with virulent yeasts of Paracoccidioides brasiliensis. Mycopathologia 2014, 178, 177-188, doi:10.1007/s11046-014-9801-1.

74. Silva, L.B.R.; Dias, L.S.; Rittner, G.M.G.; Munoz, J.E.; Souza, A.C.O.; Nosanchuk, J.D.; Travassos, L.R.; Taborda, C.P. Dendritic Cells Primed with Paracoccidioides brasiliensis Peptide P10 Are Therapeutic in Immunosuppressed Mice with Paracoccidioidomycosis. Front. Microbiol. 2017, 8, 1057, doi:10.3389/fmicb.2017.01057.

75. Silva, L.B.R.; Taira, C.L.; Dias, L.S.; Souza, A.C.O.; Nosanchuk, J.D.; Travassos, L.R.; Taborda, C.P. Experimental Therapy of Paracoccidioidomycosis Using P10-Primed Monocyte-Derived Dendritic Cells Isolated From Infected Mice. Front. Microbiol. 2019, 10, 1727, doi:10.3389/fmicb.2019.01727. 